\title{
The times are changing: resetting CSDP and European Defence*
}

\author{
Francisco de Borja Lasheras** \\ Associate Director and Policy Fellow of the \\ European Council on Foreign Relations' Madrid Office (ECFR)
}

\begin{abstract}
Summary: I. Introduction. - II. What CSDP was originally about: European strategic autonomy and power projection.-III. What CSDP is actually about. 1. A crisis management tool. 2. An Africa-centred crisis management tool? 3. An EU's security and defence diplomacy tool? 4. A framework for limited military capability cooperation and defence industry. - IV. Time for complacency? The flaws of the "building Europe" agenda. - V. The hollowing out of St. Malo? - VI. CSDP's feasible strategic purpose.-VII. Europe's strategic moment. 1. America's strategic withdrawal from Europe. 2. Continuing dependence on America and limited strategic autonomy. 3. The demilitarization of Europe-and its de-securitization. 4. Outsourcing security 5. Shelving St. Malo?-VIII. The end of old European Defence: towards a new European Defence agenda.
\end{abstract}

\begin{abstract}
The EU's Common Security and Defence Policy (CSDP) has not brought about the step change in European Defence hoped for by some of its proponents. It could not, given the EU's very nature and the different security ambitions and priorities of Member States. It has a purpose, though, as a crisis management tool for soft security tasks, mostly through civilian missions. It can sometimes embody European solidarity for actions led by coalitions of willing Member States, most recently, in Sahel. Overall, Europe faces a strategic momentum, not least with the US pivoting towards Asia and core European players re-shifting policy priorities. The old goal of a fully autonomous European Defence will not come to pass anytime soon, as Europe's defence crunch threatens to jeopardize even minimal goals of limited strategic autonomy. The way forward is a more flexible and realistic approach, emphasizing coherence between the different cooperation frameworks in Europe (NATO, EU, bilateral clusters, etc.), underpinned by stronger strategic convergence.
\end{abstract}

Key words: CSDP, strategic autonomy, power projection.

* Recibido el 30 de enero de 2014, aceptado el 12 de febrero de 2014.

** The author would like to thank Dr. Luis Simón (Institute for European Studies, Vrije Universiteit Brussel) for his valuable comments on an initial draft of this article. 
Resumen: La Política Común de Seguridad y Defensa (PCSD) de la Unión no ha supuesto un cambio fundamental en la defensa europea que sus artífices esperaban. No podría ser de otra manera, dada la naturaleza de la Unión y las diferentes prioridades estratégicas de sus miembros. Tiene una finalidad, sin embargo, como instrumento de gestión de crisis para tareas de seguridad limitadas y puede actuar como plataforma de solidaridad en apoyo de operaciones dirigidas por Estados Miembros, como en Sahel. Europa se enfrenta a un momento estratégico, ante el pivot de Estados Unidos a Asia y el consiguiente replanteamiento de políticas por Estados Miembros clave. El viejo objetivo de una Defensa Europea independiente no se va a realizar a corto plazo, dada la crisis de defensa en Europa, que podría hacer inalcanzables incluso objetivos de autonomía estratégica limitada. Es necesaria una perspectiva más flexible y realista, que busque establecer coherencia entre los distintos marcos de cooperación en Europa (OTAN, UE, acuerdos bilaterales o trilaterales, etc.), sobre la base de una mayor convergencia estratégica.

Palabras clave: PCSD, autonomía estratégica, proyección de poder.

\section{Introduction}

EU discussions are inevitably self-centred. The perennial search for purpose of the EU vis-à-vis its citizens and the outside world, coupled with the struggle to broker compromises among its almost 30 states (and their different constituencies) on issues as varied as the euro crisis, foreign policy or the quest for competitiveness. Not to mention the never-ending institutional puzzle of sorting out how the unwieldy EU is to govern itself - which naturally hampers its efforts on slightly more relevant matters, such as shaping global governance.

But even by EU standards, policy debates on the Common Security and Defence Policy (CSDP) have been particularly self-absorbed, parallel to a CSDP development agenda often pursued for the very sake of "building Europe". An agenda sometimes detached from the very strategic goals that CSDP should foster-contributing to European security as a whole and its capacity for decisive action in the face of crises. This has for years translated into fruitless diplomatic battles and turf wars over the roles of NATO, EU-and the US.

In light of CSDP's shortcomings and the fact that it has not led to a step change on European Defence, many naysayers have rushed to declare its death as a project or its irreversible coma. ${ }^{1}$ CSDP is a well-known story about gaps between expectations and actual delivery. There is indeed an

1 TECHAU, J., Forget CSDP, It's time for Plan B, 26 August 2011, at http://www .carnegieeurope.eu/2011/08/26/forget-csdp-it-s-time-for-plan-b/bkge. 
abyss between the official EU agenda to strengthen CSDP as a common tool, and the real security policy of key Member States, reflected in what they do or they do not do. In international politics, reputation matters a great deal. And the EU's reputation as a security actor has been severely tarnished after its missing in action in crises such as Libya and Mali, where its role was rather secondary. In fairness, it has assumed stabilization and capacitybuilding tasks in these and other scenarios-crucial matters in security affairs, if not always as visible in the spotlight as a military operation. Yet that has not assuaged the impression that the Union cannot be a leading forum for European security and that its military ambitions are hollow.

Still, doomsters sometimes overdo the argument for dismissing CSDP. Some such dashed expectations are reflective of nowadays' European security realities as a whole and thus also beset NATO. The EU might be struggling to conduct a joint security policy, but so is NATO, its new Strategic Concept notwithstanding. This explains the shift by several European countries, core players included, away from NATO and EU onto practical cooperation projects with like-minded strategic countries i.e. the 2010 Franco-British Lancaster House Treaty on defence. However, even if NATO is in question, CSDP has more to lose from this trend towards bilateralism or different ad hoc arrangements, not least due to the fact that it stands on shakier ground.

However, CSDP might be in coma, but it is sending some life signals, for instance, in the form of different missions in the Sahel, including its first military operation since 2008, in the Central African Republic. 2013 witnessed the holding of the first European Council with CSDP on the agenda since the outbreak of the financial and economic crisis. Discussions towards some opening of defence markets in Europe, with the Commission's involvement, are underway. And the EU wields CSDP as one of its pillars for its comprehensive approach to security and crisis management, including in broader security dialogues with partners.

After taking stock of what CSDP has achieved and what it will probably fail to deliver, this article argues that practice - and not policy discussionsmay be providing CSDP with a specific scope and thus a certain strategic purpose. It has become a crisis management tool that contributes, mostly as a repository of training and assistance tasks, to wider security efforts in scenarios. These scenarios roughly match European foreign policy priorities - particularly, in the Southern neighbourhood. If adequately used, it can also be a potential defence diplomacy tool within the EU's external toolkit and a platform for capability cooperation with old and new partners.

This is well below the initial-and perhaps unrealistic-aspirations for the EU as a backbone for a joint, credible European military capacity. Due to its own limits, the EU will remain an asymmetric security actor, 
struggling to play decisive roles in the face of core geopolitical challenges. It will generally prefer bringing to bear civilian instruments to a crisis situation than hard power tools, bar extreme-case scenarios. But a security actor nevertheless, embedded in a network of multilateral arrangements and broader diplomatic efforts led by powers and other institutions. And, importantly, CSDP can also provide meaning to the concept of European solidarity, in support of actions led by Member States, in Sahel or elsewhere, even if that support is generally centred on assistance tasks.

Overall, CSDP and the project of European Defence must be placed in the context of broader developments defining a strategic moment for Europe. Some such developments affect the core tenets of its security since the end of World War II, such as the US strategic withdrawal from European security (and hence from NATO), or the progressive demilitarization of the continent, accelerated by the defence crunch and a public mood averse to military and security in general. Faced with these far-reaching changes, major players in Europe, such as France and the UK, are recalibrating their established policy preferences as they try to retain power projection capacities.

European policymakers would do well in taking note of such trends and reassess the project of European Defence accordingly. It is time to put aside old paradigms and fruitless discussions. A new vision on European Defence could emerge that emphasizes greater coherence between existing cooperation frameworks, whether multilateral (NATO, EU) or bilateral. Less institutional theology is badly needed. Instead, we need a more practical, flexible approach that harnesses cooperation opportunities and provides them with a broader, if looser, strategic narrative aimed at enhancing Europe's security as a whole and stemming its marginalisation in world affairs.

\section{What CSDP was originally about: European strategic autonomy and power projection}

CSDP has often been criticized for being bereft of a shared strategic vision. It is partly true and different visions of its purpose have hampered the project. Its birth resulted from an ambitious strategic gamble, though, embodied in the 1998 Franco-British agreement at St. Malo. St. Malo, at bottom, was a tit-for-tat between French and British visions of European security. On the one hand, France accepted that any European Defence through the EU would be compatible with and complementary to NATO's basic collective defence - a British red line. On the other, Blair's UK endorsed the idea that the EU should be bestowed with some security and defence powers, thus endorsing a French priority, in line with Paris' consistent pursuit of strategic independence from America. 
Just as importantly as the question of Europe's political and strategic autonomy was the need to revitalize Europe's military projection. This was maybe the key lesson the British and the French extracted from the Balkan wars. Europe's foremost military powers tried to "pitch their strategic vision through the EU". ${ }^{2}$ The broader expectation was that, gradually, the responsibility of Europe's security would have to be shared by other countries beyond the unofficial triumvirate (US, UK and France), at least in Europe's backyard and neighbourhood.

Surely national considerations played a role, such as the perception of multilateral institutions as enablers of national interests - a reality that has driven European integration from the outset. And maybe it was the result of particularly conducive circumstances, domestically in key EU Member States, and at EU level in general. But, in hindsight, St. Malo was a reasonable balance between European power dynamics and the bloc's collective potential.

\section{What CSDP is actually about}

It is a matter for contention whether St. Malo was realistic, or rather a bridge too far or a bridge too soon. ${ }^{3}$ But this initiative gave birth to the then ESDP, launched by the European Council of Cologne in 1999. The fifteen years since Cologne have witnessed unprecedented developments of institutional machinery-building; some 30 civilian and military missions under EU flag in places as diverse as the Balkans, Afghanistan, Aceh or the waters off Somalia, and a capabilities agenda under the aegis of the European Defence Agency. CSDP has gained a dynamics of its own, even if it has not always pursued with the same vigour.

For a policy or, rather, a policy project of a relatively short life, CSDP has already undergone different stages of climax and drama: from the initial enthusiasm which witnessed its inception, to a certain disenchantment, to its trumpeted demise in the wake of Libya and Mali. Lastly, it might now be undergoing a certain revival, as manifested by the launching of different operations in Sahel and project tasking by European Heads of State and Government.

But the general impression is that CSDP's initial momentum has been lost and that deep-seated divisions - and different national prioritiesstand on the way of truly ambitious progress. The fact that this has taken

2 SIMÓN, L., "No might, no right: Europeans must re-discover military power", Real Instituto Elcano n. ${ }^{\circ} 19$ March 2013, p. 3

${ }^{3}$ Ibid. 
hold under a new treaty framework designed precisely to strengthen the EU's position as a global actor is quite paradoxical. ${ }^{4}$ In this regard, High Representative (HR) Ashton has been spared no criticism in the overall slowdown of momentum or even stalling of CSDP, given her apparent lack of any interest in boosting CSDP and in military affairs in general. ${ }^{5}$

For now and leaving aside for a moment questions of politics and strategy, in practical terms, what has this decade and half of frantic CSDPbuilding agenda actually achieved? For all the byzantine discussions of grand frameworks, institutions and headline-grabbing summits, nothing is more telling as to where Member States see that their policy priorities lie than two aspects: i) where they end up putting their money, resources and personnel; ii) which issues, tasks, responsibilities and risks they agree to undertake jointly.

On this basis, today's CSDP has several dimensions: an EU crisis management tool, mostly, but not exclusively, civilian; focused on its broader neighbourhood and, predominantly, Africa; a component of the EU's diplomatic machinery, and, finally, a framework for limited military capability cooperation among Member States, centred on some multinational projects.

\section{A crisis management tool}

CSDP's first and foremost dimension is that of a crisis management tool for EU's involvement in select overseas scenarios, to perform mostly soft security tasks. This is coherent with the overwhelming policy emphasis in Brussels on crisis management, which pervades all security related discussions. And it reflects the majority of Member States' preference to focus CSDP operations at the lower end of the security spectrum, prioritizing civilian missions over military operations.

Specifically, CSDP's increasing focus lies on training and advisory tasks. At least in the current political circumstances reigning in the EU and during HR/VP Ashton's tenure, capacity-building of partners has gained traction as a core-if not the core-capability ${ }^{6}$ of CSDP. Put differently, this is the minimal common denominator that results from the complex diplomatic haggling over CSDP engagement.

${ }^{4}$ MENON, A., "European Defence from Lisbon to Libya", Survival, June-July 2011.

5 Lady Ashton has often been criticized by European diplomats for her apparently lukewarm reaction to Member States' initiatives in defence and lack of interest to CSDP in general. Her absence in key meetings of Defence Ministers convened by the Spanish and Belgian Presidencies are also much referred to.

${ }^{6}$ Final Report by the High Representative/Head of EDA on the Common Security and Defence Policy, 15 October 2013, p. 7. 
Such type of missions (e.g. Rule of Law, Security Sector Reform, etc.) represent the backbone of the EU's involvement through CSDP, certainly in recent years. ${ }^{7}$ These missions are mandated to advise, train, support and assist, arguably replicating the template of other security arrangements (for instance, OSCE missions). So-called executive or enforcement tasks are the exception. Even when the missions may be bestowed with enforcement powers, the general EU preference is for a soft, selective application of such powers, and a fundamental emphasis on capacitybuilding. ${ }^{8}$

The EU thus does crisis management, mostly through civilian missions and tools. Indeed, the overwhelming majority of CSDP missions have been either civilian or civil-military. ${ }^{9}$ Most recent missions involving army personnel have been limited to training tasks, even in scenarios of conflict which might have called for other operations. The recent agreement, in January 2014, by EU Ministers to deploy a battalion-size EU military operation in the Central African Republic partly bucks this trend. It is too early to tell whether it points to new openings for EU's military ambitions, or merely a one off involvement, given a unique set of circumstances (i.e. long-due solidarity with France's military actions in Africa, an impending humanitarian disaster, etc.).

Thus far, strictu sensu EU military operations have been few, not forthcoming, an uphill struggle to set in motion even by acceptable planning standards - something, though, applicable to some civilian missions tooand with surgical, time-limited mandates. The ongoing maritime operation EUNAVFOR Somalia-Atalanta is an outlier within this general pattern, as were initial operations (for instance, ARTEMIS DR Congo), where the EU-or, rather, some of its Member States-gave signs of a potential military capacity. In this regard, the EU has deployed several bridging operations: time-bound military interventions with combat-capable ground troops to carry out a mixture of peace-making or peace-building tasks in a tightly defined theatre, prior to the deployment of a bigger force with a long-term mandate and under the auspices of another international organization, such as the African Union. ${ }^{10}$

7 All four CSDP missions launched since mid-2012 (EUCAP Sahel Niger, EUCAP Nestor, EUAVSEC South Sudan and EUTM Mali) fall within this category of capacitybuilding-focused missions.

8 This is the case, for instance, with the dwindling UNSC-mandated EU forces in Bosnia under EUFOR Althea, nowadays almost wholly focused on training of the Bosnian armed forces.

9 Source: www.eeas.europa.eu/csdp/missions-and-operations

${ }^{10}$ In this category, ARTEMIS/DRC (2003), EUFOR Tchad/RCA (2008-09) and, probably, the new mission for the CAR. 
So, regardless of the famous Helsinki Goals, the mapping of scenarios for EU mass deployments in demanding scenarios and the frantic institutional agenda, there is simply no will to entrust the Union with responsibilities for ambitious operations at the high end of the spectrum. Beyond limited engagements in failed States, the EU rules out its involvement in scenarios requiring the use of force against a State, non-state or like determined adversary.

This "non-consensus" also includes open-ended, substantially large peace-keeping operations in demanding theatres or most of the myriad of modern scenarios which require peace-making over a sustained period of time. After Afghanistan, these scenarios are increasingly unpalatable for the average war-weary, budget-constrained European government, even in tested frameworks such as NATO or UN. But few countenance using the Union for any of the above operations.

CSDP deployments illustrate the continuing relevance of geopolitical and security interests in European foreign affairs - as they do in European politics in general. Although the EU is imbued with a normative narrative, CSDP has not erased geopolitics. Far from it, it is a vehicle for the management of Member States' varied security interests and strategic priorities. This is compatible with the definition of joint pan-European endeavours, when the convergence of different interests enables them. In this regard, core CSDP missions often reflect particularly acute interests from a leading European country or countries, resulting from a previous diplomatic presence, colonial heritage or, generally speaking, spheres of influence.

This leads to discussions on whether CSDP missions reflect proper European interests or mostly national preferences and security priorities - a question that can anyway be asked for many multinational security deployments. What factors tilt the balance one way or the other (national security, perception of shared security risks, solidarity, humanitarian or Responsibility to Protect-R2P considerations, etc.) is, ultimately, an ad hoc judgement. There will rarely be one single factor behind..$^{11}$ In any event, the strong role played by activist Member States pursuing CSDP operational deployments as enablers of their geopolitical presence or national security interests cannot be overlooked. ${ }^{12}$

${ }^{11}$ For instance, the reasons of the approval of the new mission to the CAR are probably manifold: humanitarian considerations for some Member States (need to avert a R2P scenario), solidarity with the French operation after Mali, etc.

12 "The composition of the majority of CSDP missions will continue to reflect the national interest of an individual EU Member State in the relevant region", TERLIKOWSKI, M., "The EU's December Defence Summit: Towards Fragmentation of European Security", The Polish Institute of International Affairs, 18 December 2013. 
Finally, whether civilian or military, CSDP missions have often been criticized or even scorned for two things: their small size in terms of deployment and the different hurdles that have hampered force and capability generation. On the former aspect, in security affairs, this might not be the most relevant criterion, though, and a case can be made that the personnel allocated has been commensurate with the task at hand-that is, small missions to implement limited mandates with limited impact. If part of a solid diplomatic European engagement, size should not be a decisive factor.

The problem is when you have a disjointed diplomacy or CSDP engagement is below what European foreign policy ambitions should warrant. This is when the issues with force and capability generation come into play, galling in some cases (i.e. the well-known slowness in meeting staff requirements with EUPOL Afghanistan, or in meeting core capability needs with EUFOR Tchad/RCA). Some shortfalls have been overcome with contributions from non-EU countries, at times leading contributors (i.e. Turkey in EUFOR Althea). And yet, when there is a reasonably solid will to engage, even if à la carte, some such difficulties can be overcome. ${ }^{13}$

\section{An Africa-centred crisis management tool?}

The EU identifies building security in its neighbourhood as an uttermost priority. ${ }^{14}$ If one looks at the trajectory of CSDP deployments, and for all the accusations of CSDP lacking a strategic compass, a first conclusion is that there is a certain pattern of concentration in what policy speak now dubs the "broader neighbourhood", ranging from Sahel to the Horn of Africa and Sub-Saharan Africa, to the Middle East, with some presence in Eastern and the Balkans. Seen in this light, deployments have roughly matched EU's foreign policy priorities.

But a closer analysis warrants more nuanced observations. Firstly, CSDP is gradually retreating from non-EU Europe and thus its contribution to security in Europe, as opposed to security of Europe, is minimal. This is particularly applicable in the Balkans - the region which conflicts strengthened the case for the creation of CSDP and which hosted several of the initial missions early in the last decade. Farther to the East, the

13 The relatively rapid approval by January's EU Foreign Affairs Council of the new military operation to CAR can be seen in this light, through a fast-track procedure, provided contributions are then made as expected.

14 "A Secure Europe in a Better World. European Security Strategy", 12 December 2003. 
only remaining mission is the monitoring mission in Georgia, where the protracted conflict with the breakaway regions of Abkhazia and South Ossetia is, at best, in a stalemate - and it is unclear whether there is political support within the EU for any extended presence. Security factors play a role in this pattern, such as the established assessment that the Balkans are stable, if volatile. Politics matter too-sending EU missions to intractable conflicts in the post-Soviet space, with other multinational efforts (e.g. the Minsk Group for the Nagorno-Karabakh conflict) failing to nurture progress, is obviously not appealing if one seeks success. Further, key Member States are reluctant to see the EU stepping in diplomatic dossiers under their responsibility. ${ }^{15}$

The second observation is that, although the EU is contributing - not only with CSDP - to the stabilization efforts in the Middle East and North Africa, these efforts are comparatively secondary when put together with the diplomatic, financial and/or intelligence presence of other actors - the latter including several EU Member States or multilateral institutions. Security presences through missions in Afghanistan, the Occupied Palestinian Territories or, more recently, Libya, can deliver tangible benefits to broader efforts, but do not turn the EU into a relevant security actor with strategic weight in the broader scheme of things. The EU comprehensive approach may be a forward-looking approach to security, but the truth is that the EU as such is not a relevant security actor in any of the regions which it defines as uttermost priorities - certainly not in the unravelling Middle East.

Thirdly, recent deployments might point to Africa and, specifically, Sahel as an emerging priority for the EU and, ideally, one of the areas where it will focus future efforts, combining institutional resources with those of Member States. Again, the geopolitical and security interests of some EU countries (chiefly, France, whose national security strategies identify this region as a security priority), are playing a key role in this apparent trend to mobilize the EU for actions in conflicts across the region.

It is too early to tell whether this pattern might reflect a growing niche for CSDP and thus a certain geographic focus. The EU should not a priori rule out CSDP engagements in other regions. Nonetheless, in the current political circumstances, it seems off the table that Europeans see CSDP as an option for Asia (i.e. through capacity-focused missios), arguably the pivotal region of these first decades of the XxIst century-hardly coherent with EU's proclaimed ambitions as a global player.

15 Interview with an External Action Service (EEAS) official, 23 January 2014. 


\section{An EU's security and defence diplomacy tool?}

Beyond missions and operations, another growing dimension for CSDP is its inclusion in the EU's varied partnerships with third actors (states or international organisations), as part of broader security dialogues with partners. The EU signs Framework Participation Agreements (FPA) for third countries' contributions to CSDP missions.

This dovetails with the understanding of security policy and international diplomacy that pervades the EU institutions. The EU has established different strategic partnerships across most regions in the world and wields CSDP as part of its comprehensive approach to security, which aims to bring together diplomacy, financial resources, development and the whole gamut of external action tools.

It might be a bit far-fetched to argue that CSDP is a substantial element of a joint European security and defence diplomacy with partners. We should rather talk of loose, broad security cooperation with partners, of uncertain impact yet. Alas this is a potentially relevant dimension if conceived as part of an ambitious strategic approach towards core geopolitical areas where Europeans have pressing interests - such as Sahel or Asia.

This underscores the relevance of the military element, if not to counter immediate threats, certainly as an instrument of statecraft ${ }^{16}$ and international influence in general, engaging with other actors' security concerns (in the Gulf, Asia, etc.). Indeed, in the modern environment, defence remains relevant as an instrument of diplomacy vis-à-vis other actors, and as such CSDP could be leveraged by the EU in its security relations with partners.

\section{A framework for limited military capability cooperation and defence industry}

Finally, CSDP, under the stewardship of the European Defence Agency, has become a framework for cooperative projects on Member States' military capabilities. The EU is supporting steps towards a more integrated European defence market and defence industry. A more integrated, sustainable and competitive defence technological and industrial base in Europe (EDTIB) is indeed an official objective. ${ }^{17}$ This would, it is argued, fulfil several interlinked goals: stem the crisis of national defence

16 WITNEY, N, "How to stop the demilitarization of Europe", European Council on Foreign Relations, November 2011.

17 European Council, Conclusions on the Common Security and Defence Policy, 19/20 December 2013. 
industries; allow countries to keep an acceptable level of capabilities through cooperative projects paving the way for economies of scale (and savings), as well as help overcome structural shortcomings and capability gaps which hamper Europe's ability to act in crucial scenarios and regional crises. Accordingly, a real EDTIB would give credibility to the idea of Europe's strategic autonomy.

Flagship EU initiatives such as pooling and sharing (PS), launched three years ago and complementary to NATO's Smart Defence concept, aim to foster multinational capability cooperation and have arguably gained some momentum with the crisis. In turn, initiatives have been tabled, sometimes led by the Commission, to open up nowadays' fragmented defence markets in Europe (market fragmentation being a thorn for the future of European Defence as a whole).

Notwithstanding, expectations that the financial crisis affecting Europe since 2008 would usher in a new stage of European military cooperation, including steps towards a more integrated EDTIB, have thus far been dashed. The ongoing geopolitical shifts (from the US pivot and apparent strategic withdrawal from Europe and its neighbourhood, to Asia's emergence as power hub) have failed to spur a more concerted European foreign policy. The defence crisis that Europe is undergoing has also had limited impact in cementing a step change in military and defence industry cooperation.

National interests matter too much. So does the protection of national industries as well as a reluctance to tackle institutional inertias. If anything, the financial crisis has contributed to boosting national reflexes and stifling defence modernization processes. In fairness, the average MoD faces unrelenting pressure domestically from budget-slashing prone finance ministers. As a rule, they are keener to protect national assets than investing in cooperation and in European solidarity. As an example, Member States have generally carried out uncoordinated budget cuts, regardless of the impact for common security through EU or NATO. ${ }^{18}$ This is a vicious circle: defence budgets are slashed; investing in core elements for modern security, such as $\mathrm{R} \& \mathrm{D}$, has decreased exponentially, and many governments are desperately clinging to existing capabilities, which they can no longer afford.

In this regard, the crisis has re-energized the proliferation of a number of flexible cooperation clusters, bilateral or minilateral, with objectives

18 "The initial response of member states to the financial crisis has been to evoke the traditional pattern of national prerogatives in defence matters rather than a security guided rationale. The member states have sidelined NATO and the EU in identifying spending cuts. They planned and started to implement their current reforms in a rather uncoordinated manner", in "The impact of the financial crisis on European Defence", p. 11, DirectorateGeneral for External Policies, European Parliament, May 2011. 
ranging from the pooling of capabilities among small or mid-sized countries or preserving core military capabilities with like-minded strategic partners (i.e. the 2010 Franco-British defence treaty). Some argue that there is a revival of multinational cooperation through these clusters, whilst others note that actual levels of cooperation are falling. ${ }^{19}$

In general, multinational or pan-European capability projects are the exception, not the rule. Differences in power and strategic priorities among Member States naturally shape the way they embark on cooperative projects. For small and mid-sized Member States PS' initiatives are a must as is overall integration - to make up for their weaknesses - , and thus their generalised support for pooling, prioritization and specialization (through niche capabilities, etc.). Larger Member States still aim to preserve the full spectrum of military capabilities and engage in such clusters accordingly, ruling out to date prioritization or specialization, given sovereignty concerns. In initiatives for PS and multinational cooperation in general, core defence industries undeniably play a prominent role. This protection of national assets and industries' interests in opening up new markets within the EU were driving forces behind the discussions towards last December's European Council meeting on CSDP. ${ }^{20}$

So this balance between broader European interests, national interests and defence industries is not yet solved, and the dynamics of the European crisis have all but strengthened national approaches, as a stumbling block for ambitious pan-European cooperation. For some, this cannot be isolated from a broader re-nationalization of foreign and security policies at work.

Notwithstanding, EU leaders adopted in December's summit a number of decisions regarding capabilities, inter alia, concrete taskings in programmes on critical strategic enablers (drones, air-to-air refuelling, satellite communications and cyber security). The European Council also tackled the need for convergence of defence-planning, to offset this national-only which guides defence planning in Europe, through "increased transparency and information-sharing". The latter idea could eventually lead to a European defence semester of sorts, bringing to light the duplicities, redundancies and overlaps among European defence establishments. This list of taskings mandated by the EU's Heads of State and Government

19 WITNEY, N., "European Defence ten years on", European Council on Foreign Relations (ECFR), 19 December 2013, at http://ecfr.eu/content/entry/commentary_european _defence_ten_years_on 233 .

${ }^{20}$ Interviews with national defence official (November 2013), showing frustration that major players (France, UK) focused only on the defence industry aspects of the summit's agenda (the so-called third basket) and hence devoted scant attention to previous aspects, such as CSDP's effectiveness, purpose and capabilities (second and third baskets, respectively). 
has received positive assessments ${ }^{21}$ as a practical road map to boost to cooperation on core capabilities, strengthen synergies between internal and external security (also through the new role of the Commission) and lay the basis for convergence in defence planning, complementary to NATO's efforts.

Concrete taskings are now on the table, with political leaders set to assess progress in mid-2015. Yet some caution is warranted, given the overall pattern of statements on CSDP not backed by actual delivery. The fact remains that the landscape of European defence is currently one of national imperatives, an ongoing "clusterization" into thus far incoherent parts, and few major programmes and projects within either NATO or the EU. Big multinational defence projects, under EU auspices, such as the A400M programme, are the exception, and they have been hampered by financial problems, national emphasizes on national prerogatives and, lastly, raise serious questions of continuity, given financial strains. Narrow, but structural political interests will probably stand in the way of major multinational programs which could be a real leap forward as showed by the 2012 foiled merger between EADS/BAE.

Real military cooperation in Europe is not truly appealing for most governments, unless they perceive direct benefits and clear economic incentives - rationality arguments come second in policy-making as does advancing European Defence. This is testified by the fact that the summit mostly led to decisions regarding the "infrastructure" of defence (equipment and the industrial base), whilst military cooperation proposals were conspicuously absent. ${ }^{22}$

\section{Time for complacency? The flaws of the "building Europe" agenda}

As is the case with other EU policies (for instance, enlargement), the official narrative on CSDP has for years been too dotted with selfreferential, even triumphalist undertones. EU leaders and institutions tout the deployment of CSDP missions and their results as "a tangible expression of the Union's commitment to international peace and security", 23 and of the Union's "becoming an effective security provider", increasingly "recognized

${ }^{21}$ BISCOP, S. \& COELMONT, J., "Defence: the European Council matters" (Egmont Institute for International Relations, Security Policy Brief, December 2013).

22 WITNEY, N., "Despite the Brits, a modest defence summit success" (European Council on Foreign Relations, 22 December 2013), at http://ecfr.eu/blog/entry/despite_the _brits_a_modest_defence_summit_success.

${ }^{23}$ Vid. European Council Conclusions, op. cit. FN 18, p.3. 
as such" by other partners. ${ }^{24}$ This is coupled with a quantitative approach to security matters when the question is judging CSDP's effectiveness-e.g. number of missions deployed, number of local personnel trained, capabilities on paper and so forth. Other criteria, more qualitative, such as the mission's effective contribution to security on the ground and/or to broader peace efforts, or the realization of the EU's overall policy objectives are often overlooked.

This official rhetoric is understandable and hardly exclusive of the EU - an inevitable component of the politics of security affairs. With CSDP, there is a need to legitimize a relatively new policy in-the-making, particularly one as contested as CSDP. Scorning CSDP (and EU institutions) seems trendy among security pundits in light of some failures or underperformances. Yet it is pointless to ask institutions to be openly self-critical, particularly in contexts where they are assailed on many fronts (e.g. the handling of the euro crisis) and are subject to too many political interests.

But CSDP's agenda has too often been too much about building political Europe over other objectives and thus has led to too many institutional battles. The politics of CSDP plays too big a role in European diplomacy in Brussels - for instance, the persistence on the idea of a permanent EU military HQ, resisted by Britain as an unnecessary duplication of NATO. As some have argued, "an obsession with building Europe hampers the way Europeans have assessed the effectiveness of ESDP", falling prey "to the temptation of judging process rather than outcome". ${ }^{25}$

It is high time CSDP be detached from sentimental undertones, reminiscent of other times, and from the EU-centred political Europe agenda. The discussion should instead be framed in terms of CSDP's actual contribution to three core goals: Europe's security, its power projection and international peace. Hence the questions to be asked, in the view of the author, also boil down to three: i) Has CSDP delivered on these objectives, and, therefore, is it the most effective policy course? ii) Is it fitting with the times, with this Europe and in this context?; iii) Can other policy alternatives also be tested, to achieve similar objectives?

The first question regards CSDP's output and hence affects its legitimacy. As outlined above, the debate often suffers from policy asphyxia, limited to two camps: CSDP doomsters, naysayers and advocates of Realpolitik who easily mock the EU's every attempt at security affairs, and CSDP faithful who hold on to the probably mistaken belief that gradual developments in the mould of Monnet will one day lead to a common defence policy. The

24 Vid. HR Report, op. cit., FN 7, p. 3.

25 MENON, A. "Empowering Paradise: the ESDP at Ten", International Affairs 85, pp. 227-246. 
first ones often dismiss the EU outright and underline bilateral, minilateral frameworks or NATO, whereas the others all too often pick political battles over symbolic issues (i.e. the EU Military HQ), rather than trying to bridge differences with governments sceptical of CSDP's purpose.

Assessing the impact of CSDP missions and operations proper is an exercise largely beyond the scope of this paper. Some CSDP missions have generally met the limited objectives they were entrusted with (e.g. assuring for a short period of time a Safe and Secure Environment; contribute, through deterrence, to the fight against piracy, etc.). There is a stretch, though, between recognizing their contribution to security and extolling their impact, as is sometimes the case, conveniently forgetting that other factors may have played a more central role. ${ }^{26}$

CSDP has provided the EU with an additional civilian layer for its CFSP. CSDP can also encompass military components, provided by Member States, to carry out crisis management tasks mostly centred on capacity-building and in contribution to broader security objectives. It is also a relevant track for practical channels of European solidarity even in scenarios where some Member States do not see immediate interests and even in spite of all its capability generation problems and so forth. Combined with other instruments and policies, the EU has indeed made inroads towards becoming a security actor and a security provider.

\section{The hollowing out of St. Malo?}

Alas, this assessment also needs to concede that the EU, though a security player, is hardly a leading one at that. The Union lacks a decisive weight not only in the global environment it purportedly aims to shape, but in its own neighbourhood. In this respect, CSDP has not remotely entailed any ground-breaking change regarding geopolitics and power in Europe, nor decisively boosted European power as such.

This is partly due to Member States' reluctance to outsource their geopolitical and security interests, and partly a result of the Union's structural limits. Such strategic calculation of key Member States will not change dramatically, bar a fundamental step change in political integration and security convergence within the EU, unlikely to materialize anytime soon.

In the fragmented, ad hoc landscape which defines modern European security and defence, CSDP comes second or third to coalitions of the

${ }^{26}$ For instance, in Bosnia, where, between 2012 and mid-2012, this author conducted joint monitoring of the environment with EUFOR Lot Teams, other international presences, such as the OSCE, also contribute to security and stabilization. 
willing or other multilateral engagements, be they UN or NATO. It is not a security guarantee, as practice shows that Member States do not really want CSDP to substitute the classic pillars of European security and defence-eroded as they may be.

As it stands, CSDP is hardly a policy, let alone a defence policy, regardless of the Lisbon Treaty's provisions on mutual assistance, its virgin machinery and the reference to collective defence. It is rather an Instrument for Security (IS) at the hands of the Union when a constellation of circumstances - national foreign policies' activism, broad security considerations or normative goals - allow for CSDP deployments.

So, far from advancing towards the realization of St. Malo's objectives of European strategic autonomy and power projection, we are witnessing instead a downgrading of CSDP to training and advisory tasks, and its overall hollowing out as a military enterprise. ${ }^{27}$ This would arguably defeat one of the basic purposes which led to its creation: enabling Europeans to take effective military action without being systematically dependent on US leadership - and resources.

St. Malo's strategic rationale has utterly failed to materialize. If anything, such objectives seem even farther now than they were two decades ago. There are too many legacies and interests preventing this: the weight of history, geopolitics, institutional inertias and different security visions. For some, this would do away with CSDP's strategic substance ${ }^{28}$ and hence the temptation to write off CSDP altogether.

It is out of the question that CSDP's ambitions have gradually narrowed down, paradoxically, at the same pace as its development. From CSDP as a potential pillar of European Defence, a strategic tool of autonomy and power, to the ongoing military crisis in Europe and the struggling to ensure security in its immediate neighbourhood. From vague calls for a European Army to the Helsinki 60.000 deployable troops, to paper Battle Groups to, at best, a battalion-strong force for a few months in a distant African country, and so forth.

\section{CSDP's feasible strategic purpose}

Yet from a different perspective, this is not going back to a square one, pre-Malo scenario. CSDP has acquired a specific scope and purpose. As a matter of fact, CSDP developments, with their stop-and-go periods,

\footnotetext{
27 Vid. WITNEY, N., op. cit., FN 20.

28 Vid. SIMON, L., op. cit., FN 3, p. 3.
} 
reveal what is plausible for an EU-wide security policy project: a certain capacity for crisis management, generally for soft security objectives (with exceptions when key European states successfully mobilize the EU convoy), within a comprehensive approach which prioritizes multilateralism and civilian missions. In the absence of consensus on CSDP's most ambitious goals - a pillar of common defence-, this state of affairs rules out the maximalist agenda which continues to drain too much of European politics and diplomacy and whose goals fail to attract a critical mass of governments, even if on paper they are committed to the enterprise.

To put it more clearly: CSDP's narrow strategic compass is one commensurate with this Europe, which increasingly abhors military force and most military adventures bar very extreme circumstances. This Europe where Member States differ greatly on many-though by no means not all-security matters, particularly when the use of military force is involved. CSDP cannot decisively change Europe's strategic cacophony, ${ }^{29}$ although it might enable some convergence of perspectives. In addition, this scope for CSDP would also be commensurate with this EU, the institutions of which are avert to harnessing factors such as geopolitics, power and military force: an EU which continues to place emphasis on its alleged power magnetism-despite all its obvious shortcomings, even in its immediate neighbourhood-over power projection. ${ }^{30}$

This state of affairs at least guarantees some clarity. Almost two decades of political and policy discussions on NATO vs EU, on the EU as a soft or hard power, etc., may be gradually drawing to an end. The balance seems to tilt towards confirming, on the one hand, the EU as a predominantly civilian actor that can occasionally mobilize military resources under a lead nation framework and, on the other, NATO as the continuing foundation of collective defence for most Europeans and a central-but not exclusiveframework for core military actions.

So, contrary to what it is sometimes argued, CSDP does have a strategic remit, yet one that corresponds with the general tenets of the EU's specific approach to diplomacy and the world. But this is hardly the end of the matter for, in the background, the whole European security and defence foundations are crumbling down, and some of the patterns outlined are part of a broader process, Europe's strategic moment.

29 WITNEY, N. and DE FRANCE, O., "Europe's strategic cacophony” (European Council on Foreign Relations, 2013)

30 CLARKE, M., "The United Kingdom's Strategic Moment", in A question of security: the British Defence Review in an age of austerity, I.B. Tauris 2011, p. 11. 


\section{Europe's strategic moment}

Lurking behind this narrowing down of CSDP's objectives and the project of European Defence lies a deeper, multifaceted process defined by ongoing changes within Europe and without, with a far-reaching impact for the core tenets of European security. Hence, as a result, European policy-makers are revisiting conventional policy when it comes to security, established alliances, EU and NATO. At bottom, such process also pertains to internal changes in European societies, affecting political preferences with respect to public policy and the role of the State.

This is Europe's strategic moment, understood as a confluence of different trends at once full of possibilities, but also difficult to interpret and liable to rapidly evolve; a time when major choices with long-term consequences cannot be avoided. ${ }^{31}$ Much of Europe's long-term prospects in global and regional affairs lies in the interplay between these trends in the next few years and the outcome or outcomes they will lead to.

\section{America's strategic withdrawal from Europe}

A large part of the high maintenance diplomacy of European security during the Cold War and its immediate aftermath revolved around the American question, that is: the overwhelming dominance of the US in European affairs, backed by its security umbrella through NATO. The US was, above all, the big European power, a fact at the basis of balancing attempts - particularly by France - to design a security construct which provided a certain strategic and political autonomy. This thinking was one of the catalysts for the project of European Defence through the EU or the vague idea of a European pillar in NATO, leading up to St. Malo.

Yet the worry among some European policymakers is nowadays the opposite scenario: America's gradual strategic withdrawal from Europe, coupled with a more nuanced engagement - not yet outright withdrawalfrom Europe's most volatile neighbourhood, the Middle East. Indeed, the latter's prospects have skyrocketed as America's drive towards resource independence will be enabled by the shale gas revolution.

America is no doubt focused on pivoting towards Asia and on the dilemma-fraught strategy of both balancing China's rising power and integrating it in global governance structures. This policy shift, supported by President Obama, is probably here to stay. The US sees increasingly few

31 Vid. CLARK, M., op. cit., FN 31, p. 9. 
returns from investing in Europe's security, particularly given the perception that its nations remain unwilling to make burden-sharing a meaningful concept. The US will retain a certain security presence, in some aspects, of strategic relevance, ${ }^{32}$ but refocused on current priorities, not on Cold War assumptions. Nonetheless, it seems difficult to discern which combination of interests and circumstances would compel the US to enforce European security with hard power, gone the Cold War, the intervention in the wars in the former Yugoslavia remaining as the exception. ${ }^{33}$

This naturally carries far-reaching implications for NATO, the transatlantic partnership and the very foundations of modern European security. Only now Europeans are starting to pay heed to louder calls from US leaders for Europe to assume responsibilities for its own security. Otherwise, as former US Defence Secretary famously put in 2011, US Congress' willingness to foot sine die the security bill "on behalf of nations unwilling to be serious in their own defence", should not be taken for granted. ${ }^{34}$

\section{Continuing dependence on America and limited strategic autonomy}

And yet, whilst the Americans try to pivot away from Europe, the looming defence crunch in Europe, hastened by austerity policies, unaffordable legacy systems and incomplete modernisation of armies, are de facto reinforcing European dependence on America-provided security-even if this currency carries less weight with it than it hitherto used to. Such dependence has been made painfully visible in recent operations where coalitions of European countries were in the lead-i.e. Libya, where the US provided the core enablers for the French-British led intervention. Yet it runs deeper than that, as Europe continues to overall shrink armed forces, lose capabilities and shed the different nuts and bolts necessary to run autonomous operations.

On this basis, the project of European Defence has suffered from a certain dose of utopia. It is unclear whether Europe alone would have the capacity of mounting its own defence, at least in the time span of the

${ }^{32}$ In this regard, the deployment of elements of the NATO-planned missile shield in Southern Spain.

33 "The collapse of Yugoslavia in the 1990s probably marked the last time the US would be prepared to get involved in any European crisis unless its own global interests are genuinely threatened" (Vid. CLARKE, M., op. cit., FN 31, p. 13)

${ }^{34}$ US Secretary of Defence Robert M. Gates, "The Security and Defense Agenda" (Future of NATO), Speech in Brussels, 10 June 2011, available at http://www.defense.gov/ speeches/speech.aspx?speechhid=1581. 
present generation. Some argue that this would be the case, wielding overall European defence spending and the British/French nukes; some disagree and claim that Europe will remain dependent on imported security-NATO and, thus, the US. ${ }^{35}$

Either way, at the rate developments in European defence are going, strategic independence cannot be taken seriously and would probably need to be abandoned as an objective. It is not only that European strategic autonomy, as envisaged in St. Malo, seems an ever distant goal: it is that even core players such as France and the UK are struggling to preserve a watered down, limited and selective autonomy, with most relevant operations being only feasible through ad hoc supportive coalitions in NATO, EU or other. ${ }^{36}$ If this is the case with the central, though declining, military powers in Europe, then the scenarios for the rest of EU countries are grimmer. Hence it seems absurd to proclaim collective defence as an EU-wide goal, the Lisbon Treaty's mutual assistance and solidarity clauses and all symbolism notwithstanding.

\section{The demilitarization of Europe and its de-securitization}

Europe's impending defence crisis partly stems from a deeper process of political and societal change: what Robert Gates dubbed the demilitarization of Europe and, in view of this author, its de-securitization. "Defence matters", proclaimed European Heads of State and Government in last December's meeting of the European Council.

Does it? To most European populations and the same governments who agree to such statements, the reverse seems true. This is illustrated not only by the continuing budget cuts, but by the overwhelming European scepticism, if not outright dismissal, of the usefulness of the military element and the use of force in general, particularly in the aftermath of Afghanistan and Libya. The prevalent perception is that the risks of conventional attacks on European territory and populations are minimal, which makes conventional defence look outdated. But most overseas interventions are an uphill battle too, unless framed in more appealing

35 Vid. TECHAU, J., op. cit., FN 2.

36 "It is then quite paradoxical that the trend toward modernising forces by downsizing them, so as to improve deployability and influence, has produced militaries too small and incomplete, not only to be truly autonomous but even to weigh in, as Iraq and Afghanistan have shown beyond doubt" (DE DURAND, E., "Entente or oblivion: Franco-British Defence Cooperation", in A question of security: the British Defence Review in an age of austerity, op. cit., FN 31, p. 106). 
terms - peacekeeping tasks, UN-mandated, no combat tasks, etc. The picture, if one takes a closer look at the polls, is more complex, ${ }^{37}$ but the overall trend against defence seems certain.

The jury is still out on whether these public opinion trends point to the appearance of a new Europe lacking political resolve for serious diplomacy and enforcement actions ${ }^{38}$ Strategic shocks and new threat perceptions might buck this trend, as might an improvement of the economic environment.

But Europe is nowadays beset by inward-looking, niggardly moods, loathing most things that the EU is keen to shape, such as free movement or other aspects of globalisation. To some, Europe has lost its defence spirit, yet rather it would seem as though it has lost any awareness that security matters, bar immediate economic security. So it is not strange that good arguments on the need for defence fall on deaf ears. ${ }^{39}$ Plus, in a context of unrelenting cuts for public resources, affecting welfare-related allocations (health, pensions), the case for defence budgets is even harder to make.

Hence any serious project on European foreign policy or European defence, for that matter, will have a fundamental challenge to instil a certain change in public perceptions towards foreign affairs and security. Without it, short-term minded European governments will probably not miss the opportunity to do, in security and defence, as little and as late as possible.

\section{Outsourcing security}

As Europeans struggle to play a relevant role, as a bloc, in security affairs, assuring their own security first and facing problems in their neighbourhood, a parallel trend that is emerging is the outsourcing of security. Indeed, there is a growing policy stress on building capacities of local and regional partners, officially, to guarantee ownership and advance towards a wedded regional security, so that "partners can increasingly

37 For instance, the 2013 Transatlantic Trends' survey, conducted by the German Marshall Fund of the United States, showed majorities in Europe (and the US) - 58 \% and $55 \%$ respectively - believing that NATO remains essential for security, and, although clear majorities refused to back intervention in Syria, questions on other issues led to nuanced results. For instance, while a plurality of Europeans (48\%) favoured the use of force over accepting a nuclear Iran, similar question on North Korea elicited different responses depending on the EU country in question, with France (51\%) and Spain (48\%) approving the military option, and a plurality of Europeans (44\%) preferring the acceptance of a nuclear North Korea.

38 DEMPSEY, J., 16 September 2013, New York Times.

39 TECHAU, J., Why good arguments won't save European Defense, 19 November 2013, at http://carnegieeurope.eu/strategiceurope/?fa=53641. 
prevent or manage crises by themselves" ${ }^{40}$ Whilst this is indeed a relevant goal, it is also a very convenient track for the average European government, promoting this "security in the cheap".

Yet a single focus on regional capacity-building is no substitute for a proper European security capacity. Europe has failed to make a real leap forward in assuring its own security, assuming more burden-sharing with America, and sharing in responsibility for international peace and security, as proclaimed in 2003 by the first Security Strategy of the Union. But even more worrisome would be a strategic retrenchment, encouraging other actors to share in the burden of its own security-and shirking its own responsibilities.

\section{Shelving St. Malo?}

On top of these factors, it is worth underlining the ongoing policy reassessment at work in the very states that launched St. Malo. The perception in Paris and London is that their bet on a military powerhouse EU has failed, that the project of an ambitious European Defence anchored in the EU has a limited trajectory and, importantly, will not add much to these countries' power projection aims. For the French, CSDP is still worth supporting, but perhaps not with much vigour and certainly not as a single track. For the British, CSDP, with its political undertones, seems to be more of a nuisance which yields little practical progress - and, on top of that, is a hard sell for domestic politics. Whilst St. Malo brought the two countries together, bridging their strategic differences, the hollowing out of St. Malo's ultimate goals - and similar problems besieging NATO-, might force them into even closer bilateral cooperation.

France went a long way towards assuaging fears that CSDP and European Defence could only complement - and not duplicate NATO - with its 2009 reintegration in NATO's military command. But, paradoxically, although the divide between Atlanticists and Europeanists has been largely bridged, the failure to seriously advance European Defence in either NATO or the EU reveals that the underlying problem is seldom one of institutions, but rather one of ambitions, strategic priorities and security perceptions.

In such circumstances, a certain disenchantment with CSDP as one of France's pet projects seems to have taken hold in Paris' policymaking circles, broad references to European defence regardless. France's loneliness in Mali and European partners' general indecisiveness to back-up

40 Vid. European Council Conclusions, op. cit., FN 18, p. 3. 
French actions may have been the straw that broke the camel's back. This disappointment goes deeper and predate Mali, dovetailing with the failure to bring momentum in the EU as a whole, in spite of the Lisbon Treaty. ${ }^{41}$ Arguably, mistrust cuts both ways and some French engagements have been perceived by other European partners as unilateral and uncoordinated. France has been accused of keeping the EU and partners out of decisionmaking, bringing them in for purely operational or logistical supports. ${ }^{42}$

Come what may, the dominant perception of the limited returns that CSDP brings is a driving force behind an ongoing reassessment in Paris as regards European Defence, NATO and CSDP, with some hints provided by the 2013 French Defence White Paper or Hubert Védrine's 2012 Report on France's return to NATO's Integrated Command. ${ }^{43}$ This policy reset, still in its early stage, supports a more pragmatic approach to European Defence, reflecting crude national interest rationales - rhetoric aside, a main driver for French policy on Europe. In this view, the priority would be to pursue ad hoc, case-by-case engagements in the different frameworks (NATO, EU) and with specific European partners. ${ }^{44}$ A ruthlessly practical agenda. The dominant mood in Paris these days stresses flexibility to pursue national objectives (and the protection of defence industry's interests) and implicitly sees Europe as a vehicle or enabler of France's power ambitions. So less theology about Europe, even if official statements will be draped in the cloak of European Defence. ${ }^{45}$

Similar factors as well as other circumstances - such as the need to recalibrate the transatlantic partnership, the UK's foremost foreign policy priority-are also pushing the British in the direction of a new strategic

${ }^{41}$ French scepticism with EU Member States' willingness to move forward on themes such as the Lisbon Treaty-based Permanent Structured Cooperation was mainstream in French circles already in 2008.

${ }^{42}$ Conversation with European diplomat, noting that the French informed of their decision to intervene very few days before sending troops, without any consultation, and asking for specific operational support.

43 "In 2012 it is pointless to ask the simplistic, black-and-white questions of whether we should be for or against NATO or for or against the Europe of Defence... The real question is how France can best defend her fundamental security and defence interests today and tomorrow...", VÉDRINE, H., "Report for the President of the French Republic on the consequence of France's return to NATO's integrated military command, on the future of transatlantic relations, and the outlook for the Europe of Defence", 14 November 2012, p. 10.

44 "France must take charge of her own destiny, both in the Alliance and in the European Union, working with some of her European partners on a case-by-case basis". "This policy needs to be implemented simultaneously within the European Union, within NATO and within ad hoc groups, using suitable tactics for each case and each organisation and with an eye to anticipate events", Ibid., VÉDRINE, H., p.24.

45 See President Holland's discourse of 14 January 2014. 
approach towards security and Europe. The fact that the UK has clearly moved from a St. Malo architect to a CSDP spoiler, blocking many of key decisions I the EU, cannot be disentangled from its present Europhobic drive. Yet a root factor is that the UK's engagement with Europe, after the Cold War, is seen as less of a strategic necessity and more of a foreign policy change-which might be changing.

Arguably, the confluence of such perceptions, both countries' limited success in their respective ambitions-Britain's loss of interest for a postAtlantic US, other Europeans' mild support to French goals - and their equal need to preserve some trappings of military powers, in light of a defence crunch, might be a factor of convergence, fostering closer bilateral cooperation, as embodied in the 2010 Lancaster House Treaty. In a nutshell, both countries are still devising ways to keep their diminishing global influence, and will engage with Europe to the extent that it might provide practical support to these ambitions.

Ultimately, this new approach is fitting with these times of self-reliance and strategic individualism in multilateral affairs, and in security issues in particular. Some other countries are also undergoing similar policy reassessments when it comes to security, defence and Europe, in an overall context of scepticism regarding the European project and the notion of solidarity - intrinsic to any project on joint defence.

\section{The end of old European Defence: towards a new European Defence agenda}

CSDP has not brought about the u-turn in European defence affairs that some of its proponents expected. Yet it has a certain strategic purpose. It is a crisis management tool for tasks at the soft end of the security spectrum, and, occasionally, it can be a repository of limited military action by Member States. If part of a coherent European diplomatic approach towards core geopolitical contexts, it could become an instrument for EU's defence diplomacy, contributing to leveraging European influence and outreach to new partners-including in Asia, the emerging global power hub. CSDP can also be a platform for more coherent capability cooperation, provided Member States are true to the word given in EU summits and move forward in the project taskings agreed. Lastly, CSDP can occasionally muster resources for actions embodying European solidarity, even if the EU is not in the lead for decisive military action. Supporting broader diplomatic and stabilization efforts does matter too, although actual EU deployments often reflect a limited commitment to solving international crises and conflicts - not that unlike the patterns nowadays set by other actors, given interventionism fatigue. 
This is clearly not the power projection tool wished for in St. Malo. But CSDP developments reflect a clear European preference for soft security engagements and are coherent with the EU's approach to international relations. Therefore, rather than pursuing an institution-focused political agenda and maximalist positions which will probably lead to yet more dashed expectations, Europeans must come to terms with these realities and try other policy options.

Overall, old paradigms must be revisited. The times have changed dramatically, both within Europe and in our strategic environment. The old political vision of an independent European Defence capacity is not a distinct scenario anytime soon. The continuous hollowing out of European defence capabilities, coupled with a political culture averse to any risks (security, globalisation, etc.), makes that even the goal of limited strategic autonomy, for operations in our neighbourhood, unachievable not even by core players such as France or the UK. Almost no such operations are possible unless American back-up is factored in, even as the US are sending clear signals that their mind is in Asia and want to "lead from behind" - and disengage when politically possible. There is a growing perception that investing in either EU or NATO reaps too few benefits for the amount of constant diplomacy required. Hence the temptation in some capitals to simply pursue their interests on their own, resorting to common frameworks or "Europe" only for reasons of legitimacy, financial or operational support. CSDP without France (and, with nuances, the UK) has probably little life of its own.

Europe's strategic momentum is here and the dilemmas it raises are far-reaching. If some of the current policies described are not reverted, the goals of Europe or the EU as a global power would be unrealizable. So far, the prospects, at best, is a limited and problematic capacity for limited presence in the neighbourhood. And an overall landscape of smaller countries incapable of neither assuring their own security nor shaping global changes relevant for their future.

Therefore the ultimate goals of St. Malo remain even more pressing nowadays. But the path to be followed requires, first and foremost, a renovation of the European political project, cementing the much needed solidarity and trust, key elements that the euro crisis has depleted, and, secondly, a more flexible approach for harnessing Europe's potential as a security actor. When it comes to defence, these are not times for theology or flagging Monnet: the gradualist vision does not work in the face of different national security interests, different levels of ambition and different political cultures. The way forward should muster the potential in the different frameworks of European defence cooperation, whether in NATO, EU and clusters, and try to establish coherence, through shared political goals. 
Establishing coherence between the different pieces of the puzzle which defines European security would benefit from a strategic convergence which CSDP - nor NATO's Strategic Concept-has triggered. The tasking at the European Council for the next High Representative to come with a global strategy by 2015 could be a step forward. ${ }^{46}$ Yet it must be coupled with synergies at other levels (i.e. EU and NATO, clusters, joint projects by pioneer groups of willing and able countries, etc.), for the EU is not and, probably, will not be Europe's central security hub.

Ultimately, Europeans must want it themselves - not just politicians or policy analysts -, that is: stemming Europe's marginalisation in world affairs and assuring their own security against crises which can bring it down with the uttermost speed (think, for instance, the global implications of a war in South-East Asia). Come what may, these are times for tough choices and the ball is in Europe's court. Nowhere else.

46 "Why Europe needs a Global Strategy", European Council on Foreign Relations (November 2013). 